\title{
Use of walking tractor powered rotary tiller in no-tillage system ${ }^{1}$
}

\author{
Uso de sulcadores rotativos acionados por trator de rabiças em semeadura direta
}

\author{
Fabricio Ardais Medeiros ${ }^{2 *}$, Ângelo Viera dos Reis ${ }^{3}$, Antonio Lilles Tavares Machado ${ }^{3}$, Roberto Lilles Tavares \\ Machado $^{3}$ e Giusepe Stefanello ${ }^{4}$
}

\begin{abstract}
Brazilian family farming has at its disposal planters whose furrowing mechanisms, whether disc or shank, require a large vertical force. In smaller planters, this is reflected in low efficiency when opening the furrow or in a high demand for mass (weight). Rotary furrowers require less vertical force for the same operation. This study aimed to evaluate the technical feasibility and performance of rotary furrowers mounted on the powertrain of a walking tractor working under direct seeding, and compare them with shank-type furrowers using bibliographic data. The parameters used in the comparison were the depth and width of the furrow, the area of disturbed soil and the cross-sectional area of the furrow with no soil after the operation. The experiment was carried out on wheat stubble that had lain fallow for six months. Twelve treatments were employed in a factorial design: three models of rotary furrowers, two values for revolutions per unit of linear displacement, and two forward speeds. The variable, cross-sectional area of the furrow with no soil, was statistically affected only by the factor, furrower. However there was significant interaction between the factors, furrower, revolutions per metre and speed, for the variables of depth, furrow width and area of disturbed soil. The values obtained for the variables of width, depth and disturbed area in the cross-section of the furrows, with the three types of rotary furrowers driven by the powertrain of a walking tractor, were similar to those generated by shank-type furrowers.
\end{abstract}

Key words: Seed furrow. Sowing depth. No-tillage system.

RESUMO - A Agricultura Familiar brasileira tem à sua disposição semeadoras cujos mecanismos sulcadores, tipo haste ou disco, demandam grande esforço vertical. Nas semeadoras de menor porte isso se reflete em baixa eficiência na abertura do sulco de semeadura ou alta exigência de massa (peso). Os sulcadores rotativos exigem menor esforço vertical na mesma operação. Neste estudo objetivou-se avaliar a viabilidade técnica e o desempenho de sulcadores rotativos, montados na cadeia cinemática de um trator de rabiças, trabalhando em semeadura direta e compará-los com sulcadores tipo haste por meio de dados bibliográficos. Os parâmetros empregados na comparação foram profundidade e largura do sulco, área de solo mobilizado e área transversal do sulco sem solo, após a operação. $\mathrm{O}$ experimento foi conduzido sobre resteva de trigo em pousio por seis meses. Foram empregados 12 tratamentos, sendo três modelos de sulcadores rotativos, dois valores de revoluções do sulcador por unidade linear de deslocamento e duas velocidades de deslocamento em delineamento fatorial. A variável área transversal do sulco sem solo foi estatisticamente afetada apenas pelo fator sulcador. No entanto, houve interação significativa entre os fatores sulcador, revoluções por metro e velocidade para as variáveis: profundidade, largura do sulco e área de solo mobilizada. Os valores obtidos para as variáveis largura, profundidade e área mobilizada na seção transversal dos sulcos com os três tipos de sulcadores rotativos acionados pela cadeia cinemática do trator de rabiças foram análogos aos gerados com sulcadores tipo haste.

Palavras-chave: Sulco de semeadura. Profundidade de semeadura. Sistema de plantio direto.

\footnotetext{
*Autor para correspondência

${ }^{1}$ Recebido para publicação em 17/02/2013; aprovado em 30/10/2014

Parte da Tese de Doutorado do primeiro autor apresentada ao Programa de Pós-Graduação em Sistema de Produção Agrícola Familiar, Universidade Federal de Pelotas

${ }^{2}$ Núcleo de Inovação em Máquinas e Equipamentos Agrícolas/NIMEq, Faculdade de Agronomia Eliseu Maciel/FAEM, Universidade Federal de Pelotas, Campus Universitário, Caixa Postal 354, Pelotas-RS, Brasil, fabricio.medeiros@ufpel.edu.br

${ }^{3}$ Universidade Federal de Pelotas, bolsistas de produtividade do CNPq, areis@ufpel.edu.br, lilles@ufpel.edu.br, rlilles@ufpel.edu.br

${ }^{4}$ Universidade Federal de Pelotas, Pelotas-RS, Brasil, giusepest@gmail.com
} 


\section{INTRODUCTION}

Family farming occupies mainly small land units and makes up the majority of the total number of rural establishments in the country. Its greatest challenge is in adapting and organizing its system of production using technologies which are available in the market. This segment has shown great interest and the ever-increasing adoption of systems of conservation, as is the case with no-tillage (NT) or direct seeding (DSS).

Denardin, Faganello and Santi (2008) historically conceptualise DSS, since 1980, as being a complex of technological processes aimed at agricultural exploitation, considering: turning soil only in the row or seed hole, permanent maintenance of the ground cover, and the diversification of species via crop rotation. In DSS more water is available to plants near the surface and with less retention energy (DALMAGO et al., 2009).

Family farming can benefit from the advantages of DSS, associating the technique to the use of small machinery. However, the supply of suitable machinery to its needs is poor, particularly in relation to agricultural implements for low-powered tractors. As a result, there are limitations on the adoption and use of DSS by these farmers. There is therefore a need and an opportunity for the improvement of such equipment (RICHTER; CAMPOS; BENASSI, 2002; ROMEIRO FILHO, 2012; TEIXEIRA, 2008).

In seeding machines, the furrowing assembly is one of the most important mechanisms for the success of direct seeding, performing the functions of straw cutting, soil decompaction and furrowing along the seed row (MACHADO et al., 2005). According to Siqueira (2010), when operating under DSS, these mechanisms present problems and operational limitations which, due to the types of furrower used (disc, shank or combination), require a large vertical force to operate at appropriate depths. For Mion and Benez (2008), the vertical load influences the working depth of the furrow-opening mechanisms, and consequently the area of turned soil, resulting in insufficient soil depths or high weight demands, and consequently greater power requirements and lifting capacity of the three point coupling system of the tractor.

For Chang (2004), rotary furrowing tools require less vertical force than do shanks, discs or a combination of the two, to operate at suitable depths. Therefore a device with a rotary furrowing tool requires less weight compared to the furrow-opening systems of direct seeding machines currently available. The author reports that over $90 \%$ of the total energy used in these models comes from the power take-off, whose energy use efficiency is greater than $90 \%$, as opposed to traction implement systems, where traction force alone operates with an efficiency of around 50\%. Reis et al. (2002) however found that the use of a planter with rotary furrowers increases slippage of the tractor drive wheels and fuel consumption.

Little information is found in the literature on rotary furrowers, confirming the need for new studies into developing suitable machines for sowing operations with this type of mechanism. In walking tractors the powertrain for the rotary hoes makes it possible, by adjusting and adapting rotary furrowers, to design a tractor-seeding system with rotary furrowing mechanisms.

This work aimed to evaluate the technical feasibility of using for direct seeding three models of rotary furrower driven by walking tractor, comparing performance data with the performance data of shank furrowers found in other studies.

\section{MATERIAL AND METHODS}

The experiment was carried out in an area located at $31^{\circ} 48^{\prime} 04^{\prime \prime} \mathrm{S}$ and $52^{\circ} 30^{\prime} 05^{\prime \prime} \mathrm{W}$, at an altitude of $39 \mathrm{~m}$, lying fallow for six months after the wheat harvest, and having been used in the previous five years under a DSS of soybean, oats and wheat. The soil in the area is classified as a typic eutrophic Yellow Argisol (EMPRESA BRASILEIRA DE PESQUISA AGROPECUÁRIA, 1999).

The experimental design was of four blocks of randomised plots with four replications (one in each block and one sample per replication), in a $3 \times 2 \times 2$ factorial scheme. There were twelve treatments consisting of three types of rotary furrower (varying in dimension, geometry and number of blades), two values for revolutions of the furrower per unit of linear displacement $\left(\mathrm{rev} \mathrm{m}^{-1}\right)$ and two forward speeds $\left(\mathrm{km} \mathrm{h}^{-1}\right)$, as shown in Table 1. The sample data was tested for normality by the Lilliefors and Shapiro-Wilk tests, and when these did not present a normal distribution, their square roots were used. When variance analysis showed a significant difference between the treatment averages, the Tukey test at a significance level of 5\% was applied for means comparison.

The texture and water content of the soil were determined using the methods described by Tröger $e t$ al. (2012), for samples collected, one per plot, in the layer from 0.0 to $120 \mathrm{~mm}$ deep. The mechanical resistance of the soil to penetration was determined sequentially every $10 \mathrm{~mm}$ in the range of 0.0 to $120 \mathrm{~mm}$. For this, we used a Falker model PLG 1020 digital penetrometer, with a cone diameter of $12.83 \mathrm{~mm}$, equipped with an electronic data acquisition system. For each plot, a point was set to determination penetration resistance, with five measurements being carried out per point. From the values obtained in each of 
the five measurements at the range of depths described above, the cone index (CI) was calculated. The CI for each lot being considered as the average of these five values.

To determine the dry mass of vegetation cover, the method used by Tröger et al. (2012) was employed, which uses a $0.5 \times 0.5 \mathrm{~m}$ wooden frame in a total of four samples per treatment. Vegetation, limited to that inside the framework, was completely removed with the aid of grass shears, and wrapped in paper bags for later determination of the dry mass of the collected material.
For the test, a Tobatta model M 130 walking tractor was used, having a horizontal, single-cylinder diesel engine with a rated power of $9.56 \mathrm{~kW}$ at $1,800 \mathrm{rpm}$, as well as the structure and powertrain for a rotary hoe. The " $R$ " furrower with four blades, and the " $S$ " and " $\mathrm{X}$ " furrowers with six blades were used (Figure 1). The "R" model had a width of $27.6 \mathrm{~mm}$ and a diameter of $471 \mathrm{~mm}$, the " $\mathrm{S}$ " model was $85.6 \mathrm{~mm}$ in width and $468 \mathrm{~mm}$ in diameter, and the model " $\mathrm{X}$ " was $27.4 \mathrm{~mm}$ in width and $470 \mathrm{~mm}$ in diameter.

Table 1 - Treatments with the levels for each factor and respective values for furrower rotation

\begin{tabular}{rcccc}
\hline Treatment & Furrower & $\begin{array}{c}\text { Number of revolutions per unit } \\
\text { of linear displacement }\left(\mathrm{rev} \mathrm{m}^{-1}\right)\end{array}$ & Speed $\left(\mathrm{km} \mathrm{h}^{-1}\right)$ & Furrower Rotation (rpm) \\
\hline 1 & $\mathrm{R}$ & 5.8 & 2.77 & 263 \\
2 & $\mathrm{R}$ & 5.8 & 3.88 & 379 \\
3 & $\mathrm{R}$ & 7.9 & 2.77 & 360 \\
4 & $\mathrm{R}$ & 7.9 & 3.88 & 514 \\
5 & $\mathrm{~S}$ & 5.8 & 2.77 & 263 \\
6 & $\mathrm{~S}$ & 5.8 & 3.88 & 379 \\
7 & $\mathrm{~S}$ & 7.9 & 2.77 & 360 \\
8 & $\mathrm{~S}$ & 7.9 & 3.88 & 514 \\
9 & $\mathrm{X}$ & 5.8 & 2.77 & 263 \\
10 & $\mathrm{X}$ & 5.8 & 3.88 & 379 \\
11 & $\mathrm{X}$ & 7.9 & 2.77 & 360 \\
\hline
\end{tabular}

Figure 1 - Diameter and width in $\mathrm{mm}$, view and perspective of the three rotary furrowers being studied: model "R" (left), "S" model (centre) and Model "X" (right)
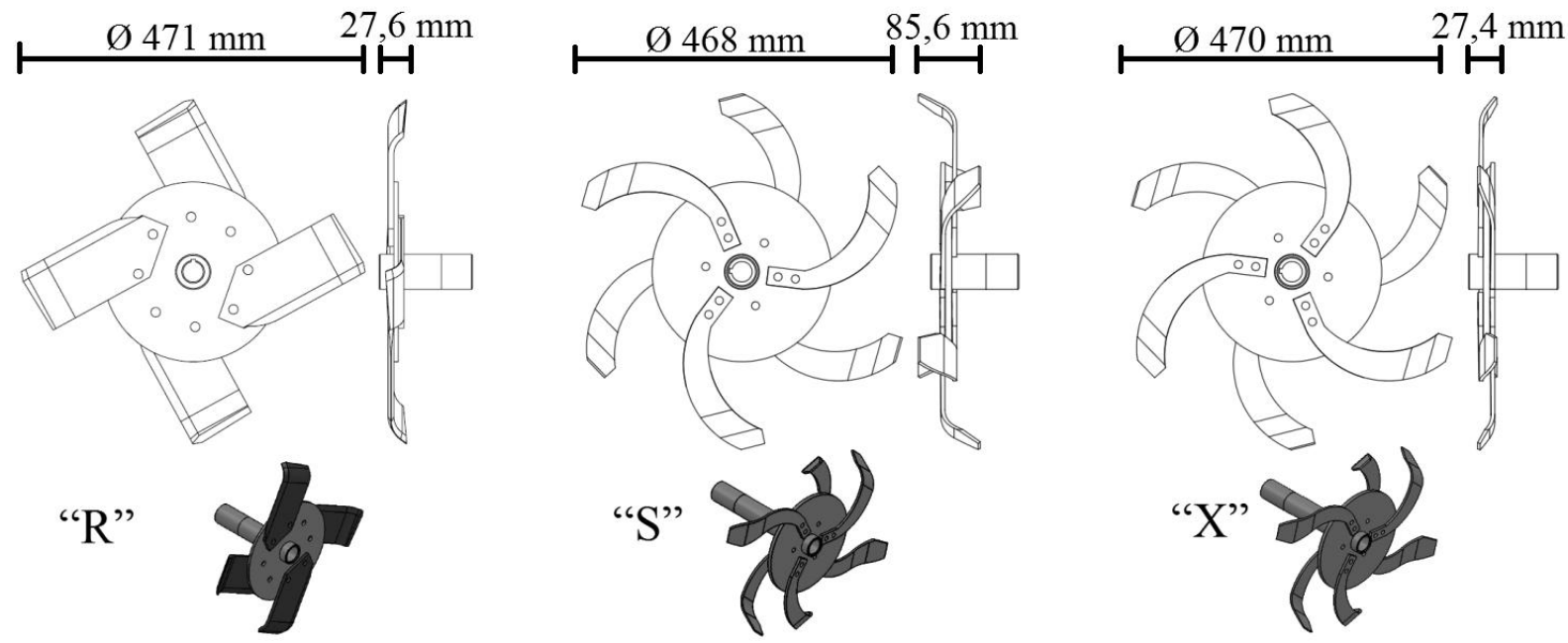
The two values used for the number of revolutions per unit of linear displacement were obtained from the drive gear ratios of the rotary hoe (Fast and Slow), which yielded values of 5.8 and $7.9 \mathrm{rev} \mathrm{m}^{-1}$ respectively. The forward speeds used were 2.77 and $3.88 \mathrm{~km} \mathrm{~h}^{-1}$, obtained respectively by the combination of pulleys at the Normal setting (reduced) in $2^{\text {nd }}$ gear, and pulleys at the Production setting (amplified) in $2^{\text {nd }}$ gear.

Because of limitations in the drive ratio combinations of the machine, the rotation of the furrower was not used as a treatment factor, due to its combination not being possible with all levels of the remaining factors in the factorial design. This means that once the level of the factor "number of furrower revolutions per unit of linear displacement" and the level of the factor "forward speed" are established, the value for rotation of the furrower, which is a function of the combination of levels for these factors, cannot be changed. To put it another way, at a forward speed of $2.77 \mathrm{~km} \mathrm{~h}^{-1}$ the two possible rotations for the rotary furrower are 263 and $360 \mathrm{rpm}$, and at a speed of $3.88 \mathrm{~km} \mathrm{~h}^{-1}$, they are 379 and $514 \mathrm{rpm}$, preventing a factorial design. As seen above, the drive ratios result in four values for furrower rotation (Table 1), which in this work are secondary variables and not used as factors of variation.

To determine the profile of the soil and furrows, a profilometer was employed, placed on two stakes fixed laterally to the furrows (Figure 2A). The profilometer used was $390 \mathrm{~mm}$ wide, equipped with rods spaced $4.0 \mathrm{~mm}$ apart and a track (vertical displacement) of $450 \mathrm{~mm}$. Prior to a

Figure 2 - (a) Profilometer used, (b) original soil profile, (c) soil profile after a pass of the furrower (d) soil profile after the removal of the disturbed soil

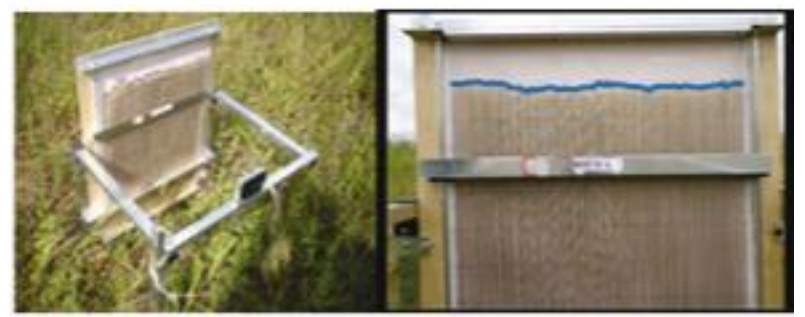

(A)

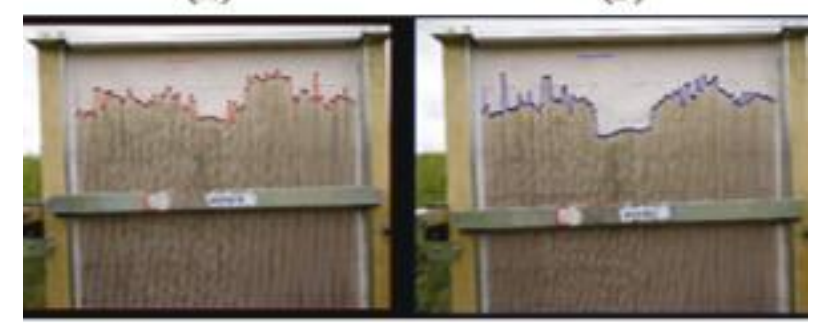

(C) pass of the machine in each plot, the natural profile of the soil surface was evaluated. After a pass of the furrower, the resulting conformation was evaluated; the profile of the furrow was determined after manual removal of the disturbed soil, for later calculation of the disturbed area, of the area with no soil in the cross section of the furrow (area of the furrow without the presence of soil below the original soil profile), and of the depth and width of the furrow. For each determination a picture was taken using a Sony Cyber-Shot digital camera with a 14.1 Mpixel resolution. For analysis of the profiles of soil and furrows, CAD software was used to measure the areas and linear dimensions based on the digital images (Figure 2).

\section{RESULTS AND DISCUSSION}

In relation to texture, the soil was characterised as sandy loam: sand $\left(63.19 \mathrm{~kg} \mathrm{~kg}^{-1}\right)$, silt $\left(20.78 \mathrm{~kg} \mathrm{~kg}^{-1}\right)$ and clay (16.06 $\mathrm{kg} \mathrm{kg}^{-1}$ ). The predominant ground cover in the area was composed of $45 \%$ Jamaica crabgrass (Digitaria horizontalis), 23.75\% Plantain Signal Grass (Brachiaria plantaginea), 20\% Arrowleaf Sida (Sida rhombifolia L.), 3.75\% Ipomoea ramosissima and $7.5 \%$ other species, including wheat straw. Soil density in the surface layer was $1.9 \mathrm{~g} \mathrm{~cm}^{-3}$ with a gravimetric moisture content of $0.13 \mathrm{~kg} \mathrm{~kg}^{-1}$ (for the 0.0 to $120 \mathrm{~mm}$ layer). Data relating to the physical characteristics of the soil, water content and the vegetation cover in the experimental area, with their relative statistical analyses, are shown in Table 2.

During operation of the of the model " $\mathrm{R}$ " furrower, plants, especially Ipomoea ramosíssima, became entwined around the axis (Figure 3). This can be explained by the angle of attack of the blades, which directs material towards the axis. The problem did not occur with the " $S$ " and " $\mathrm{X}$ " models, where the angle is reversed.

In Figure 4 is shown an example (treatment 7 , replication 2, furrower " $\mathrm{X}$ ", at the higher speed and smaller number of revolutions per metre) of the superimposed shape of lines generated by the ends of the profilometer rods, photographed at different stages before and after a pass of the furrower, and cross-sectional area of the furrows.

Table 3 shows the normal distribution of the data for depth (Lilliefors and Shapiro-Wilk), and for disturbed area (Lilliefors). Data for the width and void area were transformed by obtaining their square roots due to not presenting a normal distribution. They were then re-evaluated as to distribution, being considered normal by the Lilliefors test (width) and the Shapiro-Wilk test (void area).

Table 4 shows the variance analysis of the factors of variation, and interactions between factors, treatments and blocks. Variations in the levels of each factor caused no 
difference for all variables, and in some cases the interaction between two factors was significant. There was no interaction between the three factors for any of the response variables.

For the variable, furrow depth, there was an interaction both between the factors, type of furrower and number of revolutions per metre, and between the number of revolutions per metre and forward speed. At the larger number of revolutions per metre, the use of the "R" and " $S$ " model furrowers resulted in the highest average depths, the opposite being seen for the model "X" furrower (Table 5). At the lower number of revolutions per linear metre, use of the " $S$ " model furrower caused a reduction in furrow depth. This result suggests that the greater nominal width of this furrower, and the consequently larger disturbed area, requires a minimum number of revolutions per metre of linear displacement to reach the same depth as narrower furrowers.

Table 2 - Physical properties, water content and dry weight of the vegetation cover in the soil layer of the experimental area

\begin{tabular}{|c|c|c|c|c|c|c|c|}
\hline & \multicolumn{2}{|c|}{ Texture $\left(\mathrm{kg} \cdot \mathrm{kg}^{-1}\right)$} & \multirow[b]{2}{*}{ Clay } & \multicolumn{2}{|c|}{ Cone index $(\mathrm{kPa})$} & \multirow{2}{*}{$\begin{array}{c}\text { Water content }\left(\mathrm{kg} \mathrm{kg}^{-1}\right) \\
0-120 \mathrm{~mm}\end{array}$} & \multirow{2}{*}{$\begin{array}{l}\text { Vegetation cover dry } \\
\text { weight }\left(\mathrm{kg} \mathrm{ha}^{-1}\right)\end{array}$} \\
\hline & Sand & Silt & & $0-60 \mathrm{~mm}$ & $60-120 \mathrm{~mm}$ & & \\
\hline Mean & 63.19 & 20.78 & 16.03 & 140.04 & 1058.05 & 0.13 & 6725.00 \\
\hline SD & 3.54 & 2.23 & 4.26 & 117.55 & 349.82 & 0.01 & 1653.80 \\
\hline $\mathrm{CV}$ & 5.60 & 10.74 & 26.60 & 83.94 & 33.06 & 5.07 & 24.59 \\
\hline
\end{tabular}

Figure 3 - Plants entwined around the axis of the furrower (left) and blade trajectories of the "R" model with four blades (centre) and of the "S" and " $\mathrm{X}$ " models with six blades (right) at 7.9 rev.m" ${ }^{-1}$, and respective angle of attack of the blades

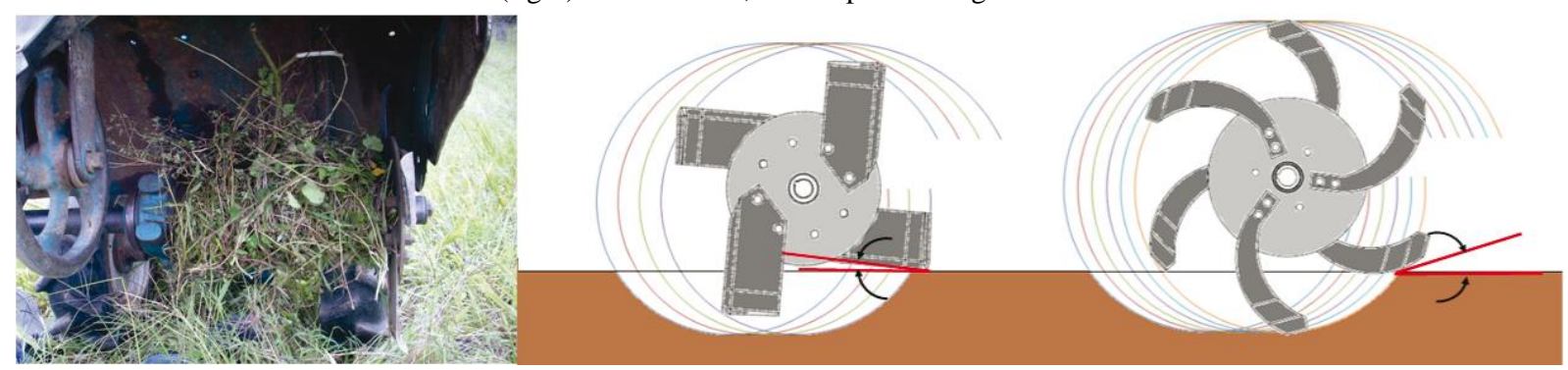

Figure 4 - Lines generated from superimposed profilometer images (A), with a key to the areas and dimensions of the furrow (B)
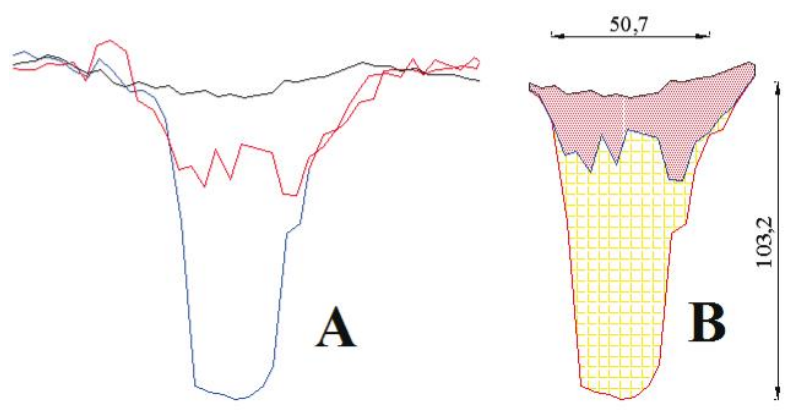

Área mobilizada acima do perfil do solo: $0,00 \mathrm{~mm}^{2}$ Área mobilizada abaixo do perfil do solo: $2.617,55 \mathrm{~mm}^{2}$

Área sem solo no sulco: $1.199,87 \mathrm{~mm}^{2}$

Perfil original do solo

Perfil do solo após o revolvimento

Perfil do sulco
The lower number of revolutions per linear metre associated with the lower forward speed caused a reduction in furrow depth (Table 5). This result can be explained by the fact of the association (the result of combinations of gear ratios) providing less rotation to the axis of the furrower, around $263 \mathrm{rpm}$. For the other combinations, the rotations varied from $360-514 \mathrm{rpm}$, as seen above (Table 1).

When considering the geometry of the furrowers (Figure 5), it can be seen that for model "X", the opposite ends of the blades are at a smaller distance from each other than are the outer vertical sides of the blades, which results in greater friction between the sides of the blades and of the furrow, making penetration of the soil difficult. Similarly, such behaviour can be compared to the effect of the latch on a saw, which when smaller makes the sawing operation difficult. This effect explains the adverse behaviour of the " $X$ " 
Table 3 - Normality tests of data from the original variables and after square root transformation

\begin{tabular}{lccccccc}
\hline \multicolumn{1}{c}{ Test } & ------------------ Lilliefors-------------------- & ------------Shapiro-Wilk------------ \\
\hline \multicolumn{1}{c}{ Variable } & Value & Crit.Val. & $\mathrm{p}$-value & Normal & Value & p-value & Normal \\
\hline Depth & 0.10848 & 0.12788 & $\mathrm{p}>0.15$ & Yes & 0.95750 & 0.07997 & Yes \\
Disturbed area & 0.10219 & 0.12788 & $\mathrm{p}>0.15$ & Yes & 0.94064 & 0.01718 & No \\
Width & 0.13293 & 0.12788 & $\mathrm{p}<0.05$ & No & 0.92135 & 0.00332 & No \\
Width1/2 & 0.10704 & 0.12788 & $\mathrm{p}>0.15$ & Yes & 0.94562 & 0.02684 & No \\
Void area & 0.21679 & 0.12788 & $\mathrm{p}<0.01$ & No & 0.81002 & 0.00000 & No \\
Void area1/2 & 0.13409 & 0.12788 & $\mathrm{p}<0.05$ & No & 0.96198 & 0,12142 & Yes \\
\hline
\end{tabular}

Table 4 - Variance analysis for the response variables

\begin{tabular}{|c|c|c|c|c|c|}
\hline \multirow{2}{*}{ Factor of variation } & \multicolumn{5}{|c|}{ Furrow depth (mm) } \\
\hline & DF & SS & MS & $\mathrm{F}$ & $\mathrm{p}$ \\
\hline Type of furrower & 2 & $1,472.04$ & 736.02 & $5.65 * *$ & 0.0078 \\
\hline Revolutions per metre covered & 1 & $2,596.02$ & $2,596.02$ & $19.93 * *$ & $<0.001$ \\
\hline Forward speed & 1 & 623.52 & 623.52 & $4.79 *$ & $<0.001$ \\
\hline Furrower x Revolutions/m & 2 & $4,465.29$ & $2,232.65$ & $17.14 * *$ & 0.0359 \\
\hline Furrower x Speed & 2 & 130.04 & 65.02 & $0.50 \mathrm{~ns}$ & $>0.050$ \\
\hline Revolutions/m x Speed & 1 & $1,131.02$ & $1,131.02$ & $8.68 * *$ & 0.0059 \\
\hline Furrower x Revolutions/m x Speed & 2 & 35.79 & 17.90 & $0.14^{\mathrm{ns}}$ & $>0.050$ \\
\hline Treatments & 11 & $10,453.73$ & 950.34 & $7.30 * *$ & $<0.001$ \\
\hline Blocks & 3 & 484.90 & 161.63 & $1.24^{\mathrm{ns}}$ & 0.3106 \\
\hline Residual & 33 & $15,236.98$ & 130.25 & - & - \\
\hline \multirow{2}{*}{ Factor of variation } & \multicolumn{5}{|c|}{ Disturbed area in the cross section of the furrow $\left(\mathrm{mm}^{2}\right)$} \\
\hline & $\mathrm{DF}$ & SS & MS & $\mathrm{F}$ & $\mathrm{p}$ \\
\hline Type of furrower & 2 & $84,861,791.29$ & $42,430,895.65$ & $40.08 * *$ & $<0.001$ \\
\hline Revolutions per metre covered & 1 & $10,152,200.52$ & $10,152,200.52$ & $9.59 * *$ & 0.0040 \\
\hline Forward speed & 1 & $4,582,470.02$ & $4,582,470.02$ & $4.33 *$ & 0.0223 \\
\hline Furrower x Revolutions/m & 2 & $9,054,108.79$ & $4,527,054.40$ & $4.28 *$ & 0.0453 \\
\hline Furrower x Speed & 2 & $3,752,204.54$ & $1,876,102.27$ & $1.77^{\mathrm{ns}}$ & 0.1857 \\
\hline Revolutions/m x Speed & 1 & $2,493,864.19$ & $2,493,864.19$ & $2.36^{\mathrm{ns}}$ & 0.1342 \\
\hline Furrower x Rev./m x Speed & 2 & $1,152,410.38$ & $576,205.19$ & $0.54^{\mathrm{ns}}$ & $>0.050$ \\
\hline Treatments & 11 & $116,049,049.73$ & $10,549,913.61$ & $9.97 * *$ & $<0.001$ \\
\hline Blocks & 3 & $1,837,854.40$ & $612,618.13$ & $0.58^{\mathrm{ns}}$ & $>0.050$ \\
\hline Residual & 33 & $34,932,034.85$ & $1,058,546.51$ & - & - \\
\hline \multirow{2}{*}{ Factor of variation } & \multicolumn{5}{|c|}{ Square root of the width of the furrow $(\mathrm{mm})$} \\
\hline & DF & SS & MS & $\mathrm{F}$ & $\mathrm{p}$ \\
\hline Type of furrower & 2 & 51.86 & 25.93 & $70.03 * *$ & $<0.001$ \\
\hline Revolutions per metre covered & 1 & 0.00 & 0.00 & $0.00^{\mathrm{ns}}$ & $>0.050$ \\
\hline Forward speed & 1 & 0.74 & 0.74 & $2.01^{\mathrm{ns}}$ & 0.0637 \\
\hline Furrower x Revolutions/m & 2 & 2.21 & 1.11 & $3.00^{\mathrm{ns}}$ & 0.166 \\
\hline Furrower x Speed & 2 & 1.11 & 0.55 & $1.50^{\mathrm{ns}}$ & 0.2385 \\
\hline
\end{tabular}


Continued Table 4

\begin{tabular}{|c|c|c|c|c|c|}
\hline Revolutions/m x Speed & 1 & 0.00 & 0.00 & $0.00 \mathrm{~ns}$ & $>0.050$ \\
\hline Furrower x Rev./m x Speed & 2 & 1.27 & 0.63 & $1.71 \mathrm{~ns}$ & 0.1961 \\
\hline Treatments & 11 & 57.20 & 5.20 & $14.04 * *$ & $<0.001$ \\
\hline Blocks & 3 & 5.46 & 1.82 & $4.91 *$ & 0.0062 \\
\hline Residual & 33 & 12.22 & 0.37 & - & - \\
\hline \multirow{2}{*}{ Factor of variation } & \multicolumn{5}{|c|}{ Square root of the void area in the furrow $\left(\mathrm{mm}^{2}\right)$} \\
\hline & $\mathrm{DF}$ & $\mathrm{SS}$ & MS & $\mathrm{F}$ & $\mathrm{p}$ \\
\hline Type of furrower & 2 & 1593.09 & 796.55 & $3.39 *$ & 0.0457 \\
\hline Revolutions per metre covered & 1 & 385.79 & 385.79 & $1.64^{\mathrm{ns}}$ & 0.2087 \\
\hline Forward speed & 1 & 438.99 & 438.99 & $1.87^{\mathrm{ns}}$ & 0.0759 \\
\hline Furrower x Revolutions/m & 2 & 1310.38 & 655.19 & $2.79^{\mathrm{ns}}$ & 0.1806 \\
\hline Furrower x Speed & 2 & 1024.05 & 512.02 & $2.18^{\mathrm{ns}}$ & 0.1290 \\
\hline Revolutions/m x Speed & 1 & 226.29 & 226.29 & $0.96^{\mathrm{ns}}$ & $>0.050$ \\
\hline Furrower x Rev./m x Speed & 2 & 460.18 & 230.09 & $0.98^{\mathrm{ns}}$ & $>0.050$ \\
\hline Treatments & 11 & 5438.76 & 494.43 & $2.11 *$ & 0.0486 \\
\hline Blocks & 3 & 520.02 & 173.34 & $0.74^{\mathrm{ns}}$ & $>0.050$ \\
\hline Residual & 33 & 7749.42 & 234.83 & - & - \\
\hline
\end{tabular}

** significant at $1 \%(\mathrm{p}<0.01)$. significant at $5 \%(0.01 \leq \mathrm{p}<0.05)$. ns not significant $(\mathrm{p} \geq 0.05)$

Table 5 - Mean furrow depths $(\mathrm{mm})$ for the factors, type of furrower and forward speed, combined with the factor, number of revolutions per metre of linear displacement

\begin{tabular}{lccccc}
\hline \multirow{2}{*}{ Revolutions per metre } & \multicolumn{3}{c}{ Type of furrower } & \multicolumn{2}{c}{ Speed $\left(\mathrm{kmh}^{-1}\right)$} \\
\cline { 2 - 6 } & $\mathrm{R}$ & $\mathrm{S}$ & $\mathrm{X}$ & 2.77 & 3.88 \\
\hline 5.8 & $80.1 \mathrm{bA}$ & $64.5 \mathrm{bB}$ & $85.3 \mathrm{aA}$ & $68.2 \mathrm{bB}$ & $85.1 \mathrm{aA}$ \\
7.9 & $103.4 \mathrm{aA}$ & $97.4 \mathrm{aA}$ & $73.3 \mathrm{bB}$ & $92.6 \mathrm{aA}$ & $90.1 \mathrm{aA}$ \\
\hline
\end{tabular}

Means with the same lowercase letters in a column and uppercase letters on a line do not differ at $5 \%$ by Tukey test

furrower, where the depth of the groove decreases with the greater number of revolutions per metre.

According to Siqueira (2010), furrowers are designed to operate at shallow depths (less than $150 \mathrm{~mm}$ ). In the present study, with the rotary furrowers set to work at a depth of $120 \mathrm{~mm}$, the furrows made by the three models varied from 49 to $118 \mathrm{~mm}$ in depth. The intended depth (120 mm) was not reached; similar to work by Cepik et al. (2010), which evaluated the furrows made by a shank at nominal depths of 60 and $120 \mathrm{~mm}$ with a cutting disc, in soil with water content between 0.14 and $0.17 \mathrm{~kg} \mathrm{~kg}^{-1}$, and at an average speed of $4.5 \mathrm{~km} \mathrm{~h}^{-1}$. At a nominal depth of 120 $\mathrm{mm}$, as the depth reached values between 115 and $113 \mathrm{~mm}$, Tröger (2012), evaluating the furrows made by shanks with six different tips set to work at a depth of $120 \mathrm{~mm}$ using a cutting disc, obtained average values ranging from 112 to $125 \mathrm{~mm}$. Silveira et al. (2011), in a test with a shank-type furrower set to work at $100 \mathrm{~mm}$, found data for average depth ranging from $111 \mathrm{~mm}\left(3.5 \mathrm{~km} \mathrm{~h}^{-1}\right)$ to $93 \mathrm{~mm}\left(7.0 \mathrm{~km} \mathrm{~h}^{-1}\right)$. The averages for furrow depth obtained with rotary furrowers show a proximity to the data for furrow depth obtained with the use of shank-type furrowers. For greater average furrow depths, consistent with the recommendations of Denardin, Faganello and Santi (2008), the three models of rotary furrower must be correctly associated with the levels of the remaining factors. For the three models of rotary furrower under study, associating the lower number of revolutions per linear metre with the lower forward speed should be avoided in order to prevent shallow furrow depths. For models "R" and " $S$ ", the larger number of revolutions per unit of linear displacement should be preferred. For model " $\mathrm{X}$ ", the smaller number of revolutions should be adopted. 
For the square root of the variable, furrow width, there was no interaction between factors. Only the factor, type of furrower, showed a significant effect, which can be explained by the difference between the nominal widths for each furrower (Figure 5 and Table 6). According to Silva (2009) and Siqueira (2010), the most appropriate furrowers would be the models " $R$ " and "X", of reduced thickness and therefore, considering the width only, more suited to direct seeding.

There was also a difference between blocks for average furrow width, with the lowest average widths occurring in blocks $1(59.0 \mathrm{~mm})$ and $2(68.8 \mathrm{~mm})$, and the highest average values in blocks $2(68.8 \mathrm{~mm}), 3$ $(71.8 \mathrm{~mm})$ and $4(72.2 \mathrm{~mm})$. The greatest value for furrow width was found in the block with the highest cone index. The furrow width was greater in blocks where the mass of vegetation cover was greater. According to Cepik et al. (2010), with furrowing shanks a larger amount of residue resulted in a greater amount of disturbed soil, which indirectly means a greater furrow width. The mass of vegetation cover in the plots showed a similar effect on furrow width as obtained when using rotary furrowers.

For the square root of the variable, area of no soil in the cross section of the furrow, there was no interaction between any of the variation factors. Of the factors under evaluation, only the type of furrower caused statistically significant changes in this variable, which had an average value of $967 \mathrm{~mm}^{2}$. However, the Tukey test showed no significant difference for the three types of rotary furrower. This is due to an inconsistency in the joint application of the $\mathrm{F}$ and Tukey tests, which rarely occurs. When the value for $\mathrm{F}$ is very close to significance, but does not quite reach it, the Tukey test may demonstrate a significant difference between the highest and lowest average, with the opposite possibly occurring. In this case, $\mathrm{F}$ was significant for a difference of only one-tenth, and the largest and smallest averages did not differ by approximately two tenths. To get round this problem, the Scott-Knott test was used, which is more sensitive to differences between means. The result of this comparison is presented in Table 6, where the difference is shown for only one of the more narrow furrowers
(R) with the lowest average area of no soil (square root) and the other averages being statistically equal.

The average values for disturbed area in this study varied from 2,694.5 to $6,945.1 \mathrm{~mm}^{2}$ (Table 7), being lower than the average values of 7,000 and $12,000 \mathrm{~mm}^{2}$ found by Tröger et al. (2012) at depths of between 112 and 125 mm, using shank-type furrowers with a soil water content of $0.13 \mathrm{~kg} \cdot \mathrm{kg}^{-1}$. These values are also lower than those of Levien et al. (2011) who found a value of $8.568 \mathrm{~mm}^{2}$ $\left(95.2 \mathrm{~m}^{3} \mathrm{ha}^{-1}\right.$, with rows spaced $900 \mathrm{~mm}$ apart) using a furrowing shank set for a depth of $100 \mathrm{~mm}$ and a water content of $0.31 \mathrm{Kg} \mathrm{Kg}^{-1}$. Whereas in comparison with the results of Mion et al. (2009), the area disturbed by the rotary furrowers was greater, seeing that those authors found a mean value of $1,671 \mathrm{~mm}^{2}$, despite the furrowing shank operating at a depth of $41.5 \mathrm{~mm}$ in soil with a water content of $0.26 \mathrm{~kg} \mathrm{~kg}^{-1}$. The data found in the present work are similar to those of Cepik et al. (2010), who when assessing a furrowing shank in soil with a water content of 0.10 and $0.14 \mathrm{~kg} \mathrm{~kg}^{-1}$, using working depths of between 60 and 120 $\mathrm{mm}$, and speeds of 4.5 and $6.5 \mathrm{~km} \mathrm{~h}^{-1}$, found mean values that varied from 2,768 to $6,116 \mathrm{~mm}^{2}$, close to those found in this study. The averages found for this variable therefore are an indication of the feasibility of its use in direct seeding. From the comparisons, it is evident that the models of rotary furrower under study produce furrows with appropriate mean values for the cross-sectional area of disturbed soil.

Figure 5 - Profile and nominal width in $\mathrm{mm}$ of the model "R" (left), model "S" (centre) and model "X" (right) rotary furrowers
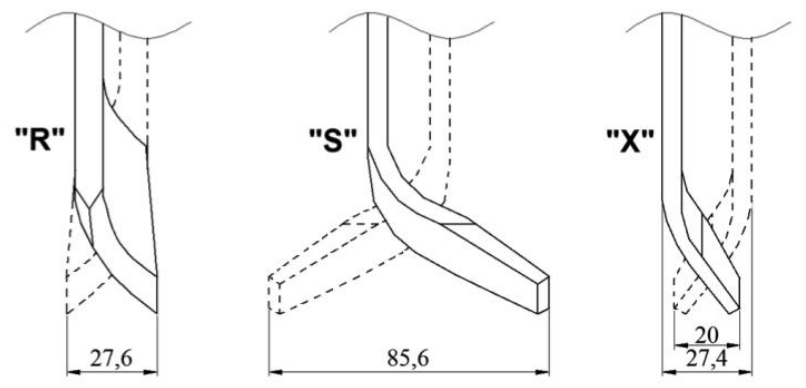

Table 6 - Averages for furrow width and area with no soil in the cross section of the furrow, and respective mean square roots, by type of rotary furrower

\begin{tabular}{lccccc}
\hline Furrower & Furrow width $(\mathrm{mm})$ & Furrow width & Area of no soil $\left(\mathrm{mm}^{2}\right)$ & Area of no soil ${ }^{1 / 2}$ & Nominal width of furrower $(\mathrm{mm})$ \\
\hline $\mathrm{R}$ & 61.63 & $7.82 \mathrm{~b}^{*}$ & 530.06 & $\left(18.02 \mathrm{~b}^{* *}\right)$ & 27.60 \\
$\mathrm{~S}$ & 91.94 & $9.55 \mathrm{a}^{*}$ & $1,393.06$ & $\left(31.06 \mathrm{a}^{* *}\right)$ & 85.60 \\
$\mathrm{X}$ & 50.25 & $7.07 \mathrm{c}^{*}$ & 977.63 & $\left(29.23 \mathrm{a}^{* *}\right)$ & 27.40 \\
\hline
\end{tabular}

Means with the same lowercase letters in a column do not differ at 5\% significance by Tukey* or Scott-Knott** test 
Table 7 - Averages for area of disturbed soil $\left(\mathrm{mm}^{2}\right)$ for the interaction between the factors, number of revolutions per metre of linear displacement and type of furrower

\begin{tabular}{lcc}
\hline \multirow{2}{*}{ Type of furrower } & \multicolumn{3}{c}{ Revolutions per meter } \\
\cline { 2 - 4 } & 5.8 & 7.9 \\
\hline $\mathrm{R}$ & $3,782.5 \mathrm{bB}$ & $5,141.0 \mathrm{bA}$ \\
$\mathrm{S}$ & $5,251.0 \mathrm{aB}$ & $6,945.1 \mathrm{aA}$ \\
$\mathrm{X}$ & $2,987.8 \mathrm{bA}$ & $2,694.5 \mathrm{cA}$ \\
\hline
\end{tabular}

Means with the same lowercase letters in a column and uppercase letters on a line do not differ at $5 \%$ significance by Tukey test

For the variable, area of disturbed soil in the cross section of the furrows, there was interaction only between the factors, type of furrower and number of revolutions per linear metre, as shown above in Table 4. In the present study there was no difference in disturbed area between blocks, therefore soil disturbance was not influenced by the type of cover present on the soil surface, nor by its mass, agreeing with the results of Herzog, Levien, and Trein (2004). As can be seen in Table 7, using the lower value for revolutions per linear metre, there was less soil disturbance with furrower models "R" and "S". With the higher value for revolutions per metre, the lowest average for area of disturbed soil was obtained with the model "X" followed by models "R" and "S".

The lower forward speed gave the lowest value for area of disturbed soil in the cross section of the furrow $\left(4,158 \mathrm{~mm}^{2}\right)$, and the higher forward speed gave the highest value $\left(4.776 \mathrm{~mm}^{2}\right)$. This behaviour was also seen in a study by Silveira et al. (2011), who found average data for the area of disturbed soil of $6,900 \mathrm{~mm}^{2}$ at the slowest speed $\left(3.5 \mathrm{~km} \mathrm{~h}^{-1}\right)$ and $9,700 \mathrm{~mm}^{2}$ at the highest speed $\left(7.0 \mathrm{~km} \mathrm{~h}^{-1}\right)$; there being an increase of $41 \%$ in the area of disturbed soil between the lowest and the highest speeds.

According to Mion and Benez (2008), greater furrow depths mean a greater disturbed area. As expected, in this study the area of disturbed soil in the cross section of the furrow varied according to the depth and width of the furrow, increasing proportionally with the increase in these dimensions. Similar behaviour was found by Herzog, Levien, and Trein (2004) for shanktype furrowers with cutting discs in native grassland, on an Argisol with an average soil water content of $0.18 \mathrm{~kg} \mathrm{~kg}^{-1}$, at $5.2 \mathrm{~km} \mathrm{~h}^{-1}$, in the 0 to $120 \mathrm{~mm}$ layer at two depths (60 and $120 \mathrm{~mm})$. The cross-sectional area of soil disturbed by the furrower was greater at a depth of $120 \mathrm{~mm}$ than at $60 \mathrm{~mm}$. Silveira et al. (2011), in a test with a rod-type furrower set to operate at 100 $\mathrm{mm}$, found average data for the area of disturbed soil of 6,900 and $9,700 \mathrm{~mm}^{2}$.

\section{CONCLUSIONS}

1. Under the conditions of direct seeding, using a rotary furrower driven by the powertrain of a walking tractor, the characteristics of width, depth and disturbed area in the cross section of the furrows are similar to those generated with shank-type furrowers;

2. The type of furrower, the number of revolutions per metre, the forward speed, or a combination of two of these factors, affect the characteristics of the generated furrow;

3. It is possible to use rotary furrowers in a directseeding system.

\section{ACKNOWLEDGEMENTS}

The authors wish to thank the Coordination for the Improvement of Personnel in Higher Education (CAPES) for granting study scholarships to the first and last authors. Thanks are also due to the National Council for Scientific and Technological Development (CNPq), Order MCT/CNPq/MDA/SAF/DATER NBR 033/2009, for financing part of the project.

\section{REFERENCES}

CEPIK, C. T. C. et al. Força de tração e mobilização do solo por hastes sulcadoras de semadoras-adubadoras. Revista Brasileira de Engenharia Agrícola e Ambiental, v. 14 n. 5, p. 561-66, 2010.

CHANG, C. S. Estudo de enxada rotativa vertical para cultivo conservacionista. In: CONGRESSO BRASILEIRO DE ENGENHARIA AGRÍCOLA, 33., 2004, São Pedro. Anais... São Pedro: Sociedade Brasileira de Engenharia Agrícola, 2004. p. 550-554.

DAlmago, G. A. et al. Retenção e disponibilidade de água às plantas, em solo sob plantio direto e preparo convencional. Revista Brasileira de Engenharia Agrícola e Ambiental, v. 13, p. 855-864, 2009. Suplemento. 
DENARDIN, J. E.; FAGANELLO, A.; SANTI, A. Falhas na implementação do Sistema Plantio Direto levam à degradação do solo. Boletim Informativo Federação Brasileira de Plantio Direto, n. 108, 2008. p. 5.

EMPRESA BRASILEIRA DE PESQUISA AGROPECUÁRIA. Sistema Brasileiro de Classificação de Solos. 2. ed. Rio de Janeiro: CNPS, 1999. 412 p.

HERZOG, R. L. da s.; LEVIEN, R.; TREIN, C. R. Produtividade de soja em semeadura direta influenciada por profundidade do sulcador de adubo e doses de resíduo em sistema irrigado e não irrigado. Engenharia Agrícola, v. 24 n. 3, p. 771- 800, 2004.

LEVIEN, R. et al. Semeadura direta de milho com dois tipos de sulcadores de adubo, em nível e no sentido do declive do terreno. Ciência Rural, v. 41 n. 6, p. 1003-10, 2011.

MACHADO, A. L. T. et al. Máquinas para preparo do solo, semeadura, adubação e tratamentos culturais. 2. ed. rev. e ampl. Pelotas: Ed. Universitária UFPEL, 2005. 235 p.

MION, R. L.; BENEZ, S. H. Esforços em ferramentas rompedoras de solo de semeadoras de plantio direto. Ciência e Agrotecnologia, v. 32 n. 5, p. 1594-600, 2008.

MION, R. L. et al. Análise tridimensional de esforços em elementos rompedores de semeadoras de plantio direto. Ciência Rural, v. 39 n. 5, p. 1414-19, 2009.

REIS, E. F. et al. Avaliação do desempenho de suas semeadoras-adubadoras de plantio direto em diferentes teores de água em um solo argiloso. Engenharia na Agricultura, v. 10, n. 1/4, p. 61-68, 2002.

RICHTER, A. S.; CAMPOS, A. C.; BENASSI, D. A. Referências em plantio direto para agricultura familiar do centro-sul do Paraná. Londrina: IAPAR. 2002. 64 p.

ROMEIRO FILHO, E. Uma abordagem centrada no usuário para o projeto de máquinas agrícolas de tração animal. Gestão \& Produção, v. 19 n. 1, p. 93-102, 2012.

SILVA, J. G. Agência de Informação Embrapa. Feijão - Plantio Direto. (2005 a 2007). Brasília, DF. 2009. Parque Estação Biológica. Disponível em: <http://www.agencia.cnptia. embrapa. br/Agencia4/AG01/arvore/AG01_102_1311200215105.html> Acesso em: 12 set. 2012.

SILVEIRA, J. C. M. et al.. Furrow depth, soil disturbance area and draft force of a seeder-fertilizer at different seeding speeds. Revista Ceres, v. 58 n. 3, p. 293-298, 2011.

SIQUEIRA, R. Milho: Semeadoras-Adubadoras para sistema plantio direto com qualidade. 2010. Disponível em: <http:// www.leb.esalq.usp.br>. Acesso em: 12 set. 2012.

TEIXEIRA, S. S. Projeto conceitual de uma semeadora de milho e feijão voltada para a agricultura familiar e agroecológica. 2008. 109 f. Dissertação (Mestrado em Ciências) - Universidade Federal de Pelotas, Pelotas, 2008.

TRÖGER, H. C. H. et al. Análise dos esforços em sulcadores empregados em semeadoras-adubadoras de baixa potência. Engenharia Agrícola, v. 32, n. 6, p. 1133-1143, 2012. 